\title{
The Rear Area of Yeniseysk Governorate in the First World War Period
}

\author{
Elena A. Romanova* \\ Krasnoyarsk State Institute of Arts \\ 22 Lenina Str., Krasnoyarsk, 660049, Russia
}

Received 14.03.2016, received in revised form 27.05.2016, accepted 29.07.2016

Due to the increased attention to the problems of studying the culture of memory and the centennium since the beginning of the First World War, the author examines the work of the Military-Industrial Committees and the railway workshops, "shoe" and the food crises, unemployment, charity in Siberian reserve regiments and treatment of the war prisoners. The paper also analyzes the resulting necessity to struggle with alcohol consumption during the wartime. The author studied the publication of newspapers, theater activities and work with political exiles, influencing the developed public consciousness in Yeniseysk Governorate. As a result there is an understanding of not only assistance to the front, but also of how the population of Yeniseysk Governorate and refugees survived during the war years.

Keywords: the First World War, the rear area of Yeniseysk Governorate, the emergence of new social organizations.

DOI: 10.17516/1997-1370-2016-9-8-1790-1798.

Research area: culture studies.

Formation of bourgeois civilization required enormous resources. General crisis of capitalism, the unevenness of its development, the fight between two military-political blocs for influence and for colonies led to the First World War. It was called the Great War, the Second Patriotic War, the Great and Imperialist War. After the start of World War II, it became known as World War I. It was one of the largest wars in human history, involving about one and a half billion people and three-quarters of the world's population.

For a long time the First World War in our country has not been adequately reflected

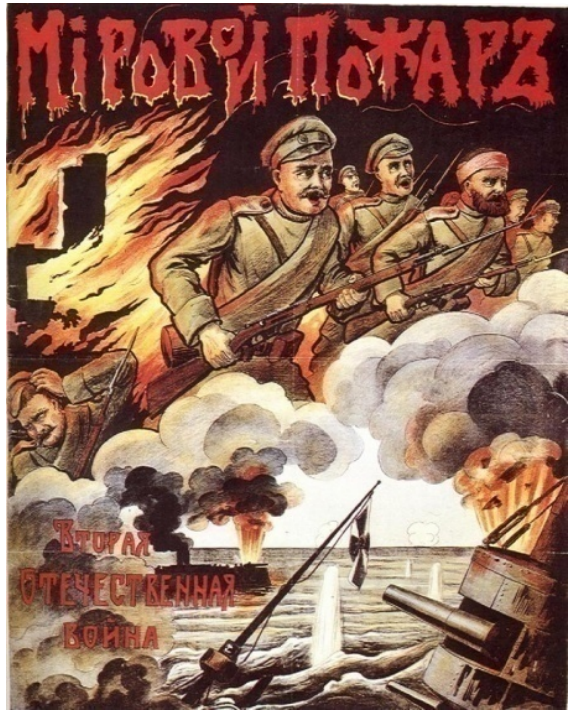

(c) Siberian Federal University. All rights reserved

* Corresponding author E-mail address: afinaadr@mail.ru 
in historical science and the mass public consciousness. In recent years, researchers have begun to pay more attention to studying the problems of the culture memory [Sviatoslavskii, 2013, p. 592], memorial policy, expressed in terms of the commemoration culture (intentional perpetuation) of the Russian state at all stages of its existence [Chernosvitov, 2013, p. 92]. First, the Soviet totalitarian culture made great efforts to destruct the historical memory, including artifacts and facts related to the First World War. Secondly, now there are communities that perceive myths as a guide to action. Thirdly, one of the basic elements of value consciousness of modern society as oriented mostly towards consumerism is a "cult of youth". And at last, the past may be modified "increasing value ranks", without losing them.

The whole country mobilized its efforts to help the front. Yeniseysk Governorate and Krasnoyarsk were no exception in this case. The city population in 1918 numbered 949,439 people. It was a strategically important territory.

Military industry of the country and regions was not ready for a long war, so a year after the outbreak of the First World War, Krasnoyarsk saw the creation of Regional Military-Industrial Committee headed by the Chairman - P.I. Gadalov. It consisted of one hundred and twelve people, twice as many as in Municipal Committee. Both of Committees were not very effective. The intelligentsia did not love them for the bureaucracy, and the Social Democrats - for support for the war. In January 1918, they were transferred to the jurisdiction of the Supreme Soviet of the National Economy Committee for the army demobilization and renamed to the People's-Industrial Committees with the obligatory confirming of the reliability of cheques and contracts concluded earlier.

The technical capabilities of the region were limited. But even in these conditions, in October
1915 Krasnoyarsk railway workshops had to cast 8500 cast iron bombs and create 40,000 cases for hand grenades. Krasnoyarsk Technical School was to produce 250 cast iron bombs and 250 lead washers for grenades [Romanova, 2014, p. 26]. The army needed weapons badly.

The state railways in the early $20^{\text {th }}$ century left much to be desired and in wartime there were many new tasks in related sphere. The military convoys from the Far East went through Krasnoyarsk. In 1915, there were two crashes: on the stretches "Taiga - Kamarchaga" and "Kamala - Zaozernaya". Two cars with bombs were derailed and eleven cars with cartridges were damaged. It was necessary to solve the problem of delivery of military cargo to the front. Special shops on duty opened to serve passengers of military transit trains better. In wartime, the Krasnoyarsk branch of the Siberian railway had to tighten technical, sanitary and food control over the military transit trains.

The Russian army needed not only arms. There was also a "shoe crisis". During the First World War, the army received more than 65 million pairs of boots, which were impossible to wear out. General A.A. Brusilov wrote in his memoirs that almost the entire population of Russia wore soldiers' boots, and most of the people heading to the front sold their boots on the road and at the front they all received a new pair. In 1915, there was introduced the provision

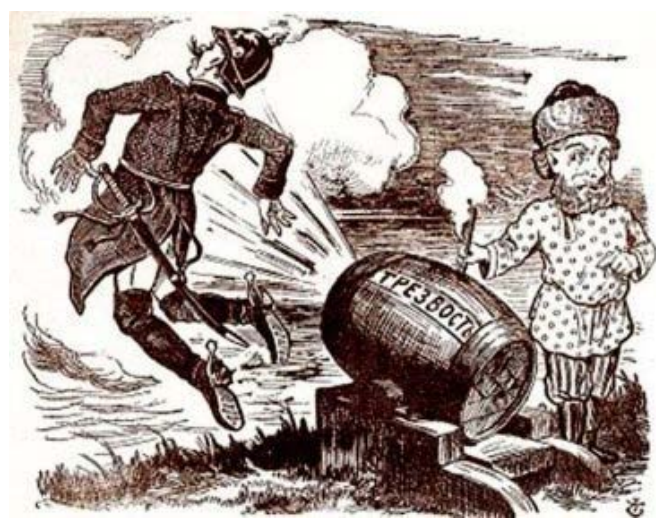


of emergency protection of military property, threatening with a prison sentence or a fine of 3,000 rubles. The taken away shoes returned to soldiers. So the problem of the "shoe" crisis in the Siberian rear area was solved in such a way.

Wartime challenges required sobriety. In 1914, the tsar issued a decree banning the production and sale of all types of alcoholic beverages in Russia. A distillery in Krasnoyarsk was closed. But in Yeniseysk Governorate there was a huge problem of secret distilling and drinking. By decision of the Governorate Committee in January 1918, traders of alcohol, convicted for the first time, had to pay a fine from one to five hundred rubles, while the convicted for the second time - from three hundred to one thousand rubles. Alcohol manufacturers were imprisoned for the period from three to six months for the first time, and for the second time - from six months to one year. Intoxicated people were subject to imprisonment, followed by public works: for the first time - from three to fifteen days, for the second time - from fifteen to thirty days. The offenders' cases were dealt with by the Revolutionary Tribunal.

In May 1918, the anti-alcohol department was abolished. In the city the policemen were in charge of fighting moonshine producers, in uyezds (administrative subdivisions) this responsibility was taken by the Soviet committees. The uyezd commissioner of Kansk people's militia imposed a fine on the residents of Alexandrovskoe village for drunkenness in the amount of one thousand rubles. People continued to struggle for a sober lifestyle.

The food crisis of wartime originated not at once. At first, the City Duma looked for opportunities to sell extra products to Japan. Later, for the year from June 1917 to June 1918, prices crept up in Krasnoyarsk. They increased in such a manner: price of bread - by $120 \%$, meat by $304 \%$, butter - by $309 \%$, kerosene - by $361 \%$, salt - by 600\% (“Krasnoyarskii Rabochii”, 1918, June 2). Butter cost a hundred and forty rubles. Meat was delivered according to ration books: a pound and a half per person per week. The cooperatives were involved in meat processing. The council of Governorate food department offered the Mongolian expedition to organize procurement of meat or to enter into contracts with the "cattle dealers" on a commission basis. There were shortages of bread. No more than 2 pounds were given to one person. The population expressed its dissatisfaction with the food crisis.

The local authorities tried to improve the system of management of food procurement. In food council of Yeniseysk Governorate the first department was in charge of buying bread for the army and the population and bread distribution; the second department was in charge of processing and distribution of meat, eggs, butter and fish; the third - the distribution of salt, sugar and tea; the seventh - requisition of foods. People tried to change kerosene and nails, threads and cotton wools, calico, felt, foot wraps, galoshes, tea and "Singer" sewing machines for the agricultural products. Despite the measures taken, the food crisis "warmed up" the revolutionary mood of the population.

The mobilization of military men to the front affected bread shortages. The villages experienced lack of manpower. On August 10, 1917 Krasnoyarsk Soviet of Workers', Soldiers' and Peasants' Deputies decided to compile lists of soldiers - "grain growers" for the issuance of vacations and assisting rural areas in the harvest time. The measure was very effective. Conversely, only a third of servicemen returned. The problem of labor in the countryside was not resolved.

Krasnoyarsk authorities used various methods to solve food problems. At the same time they did not forget even about such organizations as Krasnoyarsk City Jail. There was a daily rate of one pound of bread and two zolotniks (a zolotnik 
was a small Russian unit of weight, equal to 4.2658 grams) of sugar.

Political exiles, whose amnesty occurred in 1917, enjoyed a special attention concerning food rationing. The money was given to them by the railway workers, Abalakov's mills and State Bank. The Krasnoyarsk Committee for the Evacuation of Amnestied Political Exiles, headed by the chairman - V. Maerchak, distributed the food. During an economic crisis, they were bought ham, butter, Backstein cheese, French bread, Easter cakes and eggs, and also their cab-driving was paid by someone else. This was due to their large role in shaping the political consciousness of the Governorate inhabitants.

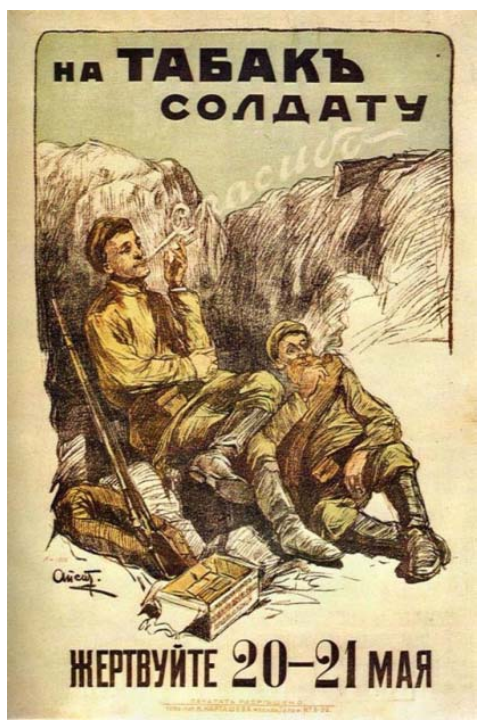

Great assistance to the front was made by the fourteenth and fifteenth Siberian reserve regiments. They held cup fees, like passing a hat, which collected more than one thousand five hundred rubles; organized charity festivals in the city park and masquerade balls, performances with military orchestras under the direction of Sukhodrev, Rogozin and others. This allowed them to provide the troops sent to the front with money.

With the outbreak of World War I, the city intensified social work with the war victims. One hundred and thirty-three city families began to receive rations. For this they required the death certificate for a family member killed in combat or the report on missing in action family member, and also the postcards from those captured. Wartime demanded tighter control over social help.

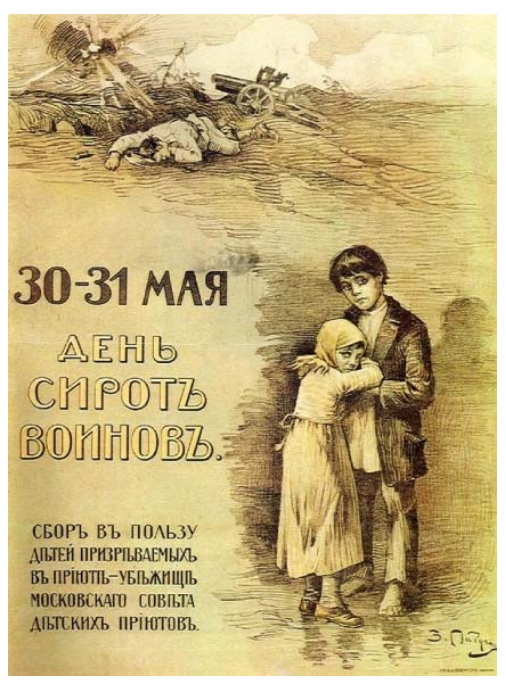

In Krasnoyarsk, new organizations of social orientation began to appear. These include female soldiers' Committee uniting the wives and widows of those who went to war. For its support people organized charity performances or allocated money from the "premium", given as an Easter present to those who worked in the railway depot. The railway depot had its own Bureau of employment. Soldiers' wives and widows were provided not only with products, but also with workplaces.

Another organization needed during the war was the Union of "maimed" soldiers. It was created in Krasnoyarsk in January 1918. The meeting of the disabled approved the general Charter, heard a report on the increase of pensions and chose delegates to be sent to the second All-Russian Congress of the Union of maimed soldiers in Petrograd. In late April, the Fraternal day was held. The second car shop of 
Krasnoyarsk railway shops made far allowances for the disabled people - the victims of World War I in the amount of 21 rubles 20 kopecks. Near the lake Shira there opened a resort for the sick soldiers and the poor people. The emergence of a new group of the population led to the formation of the Union of maimed soldiers, which was supposed to guarantee soldiers' rights.

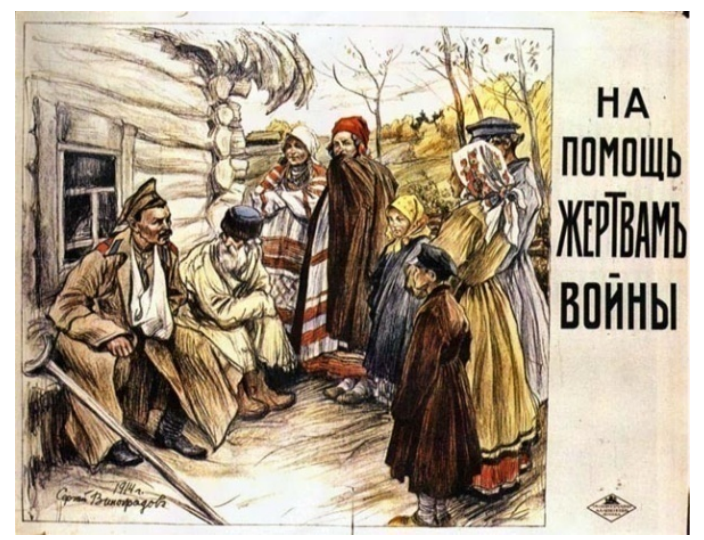

The inflow of a large number of people in Krasnoyarsk led to the creation of the Union of Refugees. In June 1918, there were 715 refugees. The Union board transferred the money to the fund "Drop of milk", aimed at assisting displaced mothers. In the context of the growing economic crisis these organizations helped to weaken its influence.

Resolution of the Governorate Committee on the hiring of workers and employees through the Employment Agency established by trade unions was published on January 31, 1918. There were 2,500 unemployed at the time. Demand was forty per cent of supply. The unemployed were former officers and demobilized soldiers, who had not worked in manufacturing before the war. For all people who wanted to work there was no enough work.

A separate system of economic measures was developed for the Russian soldiers who had escaped from captivity preceding the war end.
They were given a salary for the entire period of captivity, if they had been there against their will. In addition, the former prisoners were granted a two-month vacation. So coming back home they were of somewhat help for their families.

In Minusinsk there were courses for soldiers, the wives and widows of soldiers and workers. They studied such subjects as the Russian language, arithmetic, geography, history, nature, co-operation and political life. They had to enhance their socialization and employment skills.

Additional workforce were foreign war prisoners. In winter 1915-1916 there were 13,000 war prisoners in Krasnoyarsk, 2,750 - in Achinsk, 6,000 - in Kansk, 21750 people - on the territory of Yeniseysk Governorate (See in: The camp for prisoners of war, the $1^{\text {st }}$ Krasnoyarsk concentration camp-http://kraevushka.livejournal.com/157355. $\mathrm{html})$. Most of the prisoners lived in the capital of Yeniseysk Governorate. In the Krasnoyarsk camp there was held the lieutenant of the AustroHungarian army Bela Frankl (future writer Mate Zalka), who was taken as a prisoner during the Brusilov Offensive.

Captured officers did not work, they had a separate dining room, obtained allowance from their countries. The war prisoners - German doctors were specially monitored. The lower ranks first had the opportunity to move freely; so to earn their living they made clothes, shoes,

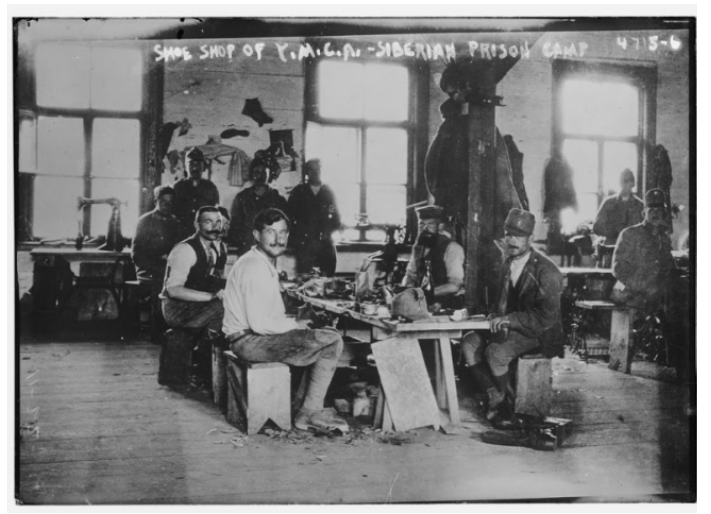


watches and sold them on the streets. Income of the war prisoners was different.

Starting in 1916 the officers of the lower ranks were used in public works - in groups of twenty-thirty people. The group was led by an officer - a prisoner of war. Under the supervision of guards, they went to the bath or to shop for food. They were recommended to go to bed at nine o'clock in the evening. Appropriate season clothing and footwear were provided by the employers. Community work for the prisoners of the lower ranks at the railway was very timeconsuming. The tasks included: pile driving, changing the rails, earthworks, coal unloading, loading ballast, construction works. There was a restriction: only prisoners who spoke the Slavic languages were taken to work. The lower rank groups accounting for between thirty to one hundred people were often reluctant to work on the Siberian railway and to go digging in NovoZlobinskii quarry. In 1915 the Krasnoyarsk authorities had the right to discipline the war prisoners. Thus, with respect to the lower ranks prisoners of war the administrative control was tight.

Prisoners earned money for themselves differently. The well-paid elite among them were soloists of the Vienna and Berlin operas. The orchestra of war prisoners performed at literary-musical parties with the choir of the Higher Primary School of the Teachers' Institute conducted by Starukhin or with the choir of the Latvian section of the People's House ("III International") of Anti-alcohol Department. Military bands earned up to 50 rubles per night.

In Yeniseysk Governorate the political consciousness of captured soldiers and officers changed. At the end of the First World War there was created the Krasnoyarsk branch of the SocialDemocratic internationalists, consisting of the war prisoners numbering 1,200 people with 5 officers-activists. This organization criticized the war in favor of the emperor and the capitalists, and it required to improve financial security as well. At the meeting they discussed the four candidates to be sent to the Congress of the war prisoners-socialists in Irkutsk. The activists were Hungarian representative - Liska and German Kolgof. A significant result of their activity was the publication of the newspaper "Vpered" (Russian for "Forward") of social-democratic orientation in German and Hungarian, which appeared in Krasnoyarsk in April 1918.

For foreign prisoners in Krasnoyarsk there were held evening K. Marx parties. The choir and orchestra performed for the prisoners "The Internationale", "Warszawianka", "Red Flag" and "La Marseillaise", "Comrades, Let's Bravely March" and "Rage, tyrants!". Valman read the poem "Oh, Do Not Cry, My Friend", Kolgof delivered a report about Karl Marx's life in German, Pattake - in Hungarian. Such evenings were a part of ideological control of the war prisoners.

Theater life in Krasnoyarsk during the First World War was quite active. The events include staging of the Trofimov's play "A Bee and Drones" by the drama circle headed by A. Koranskii in Workers and Peasants People's House; a dramatic sketch "On the Big Road"; a joke "A Tragedian in Spite of Himself" based on the works of Anton Chekhov; Nikolai Gogol's comedy "Marriage". Many performances had simplified name: "The Unemployed", "The Pistol Gun", "Satanella". In Achinsk Ostrovsky's play "Live Not as You Would Like To" was staged in the premises of the garrison meeting. There were also performances based on the classic works or the works of lesserknown authors.

For Russia, the First World War officially ended in March 1918 with the Brest peace, but its influence continued. It was not only economic and political but also cultural one. On May 1, 1918 the club "III International" saw Lagman's play 
in three acts "Bartel Turazor (Judah's money)" about the life of Austrian soldiers.

Tickets cost from fifty kopecks to one ruble fifty kopecks and were cheap compared with prices on food (bread in 1918 cost eight rubles twenty kopecks, meat - twenty-eight rubles, butter - one hundred and forty rubles). The public could afford to keep walking to the performances in the economic crisis. Moreover, they were often combined with political lectures, necessary for the formation of the mass consciousness of the population. Krasnoyarsk, Kansk, Ilansk and other cities heard the "reports" by Ia. Bograd and A. Pomerantseva on current topics, such as "The International Workingmen's Association and European war", "War and Revolution". Furthermore, the performances wereaccompanied by dance parties until three-four in the morning in order to "let off steam" in terms of prohibition (dry law).

Krasnoyarsk library created the conditions to meet the diverse interests of citizens. One of them situated at the largest Consumer Protection Society "Initiative" had three thousand six hundred books in January 1918. Of these, 30 $\%$ were of the social sciences, $40 \%$ - natural sciences, 30\% -fiction. Round the year, the libraries subscribed to various adult magazines "The Modern World", "The Russian Notes", "The Chronicle", "The International", "The Forward", "The Economic Review", "The Siberian Village", "The Companion of Cooperator" and "The Bulletin of cooperative unions". The children's magazines included "The Lighthouse" ("Mayak" in Russian) and "The Thaw Holes" ("Protalinki" in Russian). The libraries subscribed to quite a lot of national and local newspapers. The former included: "Pravda", "The Social Democracy", "The New Life" ("Novaya Zhizn" in Russian), "The Working Paper" ("Rabochaia Gazeta" in Russian), "The Forward" ("Vpered" in Russian), "The People's Business" ("Delo Naroda" in
Russian), "The Work" ("Trud" in Russian), "The Proceedings of the Petrograd Soviet Workers' and Soldiers' Deputies", "The Proceedings of AllRussian Soviet Peasants' Deputies", "The Russian Gazette" ("Russkie Vedomosti" in Russian), "The Day of Siberia". The second group included: "The Krasnoyarsk Worker" ("Krasnoyarskii Rabochii” in Russian), "The Proceedings of the Krasnoyarsk Council", "The Banner of Labor" (Znamia Truda" in Russian), "Our Voice".

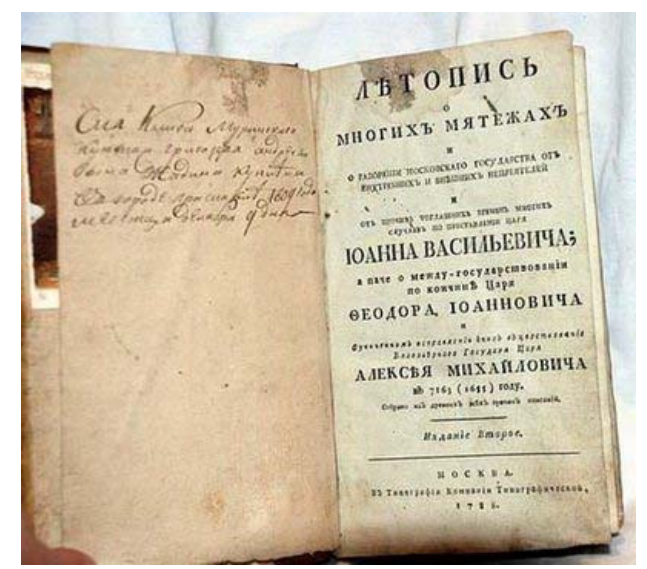

The newspaper "Krasnoyarskii Rabochii" ("Krasnoyarsk Worker") often published interviews and articles about Ukraine. A German doctor even asked the questions: "where are the borders of Ukraine? what is the difference between the Ukrainians and the Great Russians? why could not they agree among themselves? Other publications said that in Lutsk, Mykolaiv and Odessa there was nothing Ukrainian. These facts showed the aggravation of the national question, as reflected in the Siberian press.

On October 3, 1917 the newspaper "Krasnoyarskii Rabochii" published a translation from the German by A. Zickler - "Violin in the Trenches" about Franz - the musician and soldier of Vienna infantry battalion, who during the respite from war instead of the sun saw a huge chandelier of the concert hall. Struck up a Strauss waltz, he awakened the universal feelings 
among the enemies - the Italian soldiers. His violin "was complaining and moaning about the hopeless agony of the Earth, flooded by the streams of human blood". In the first place, this work was to create pacifism of Krasnoyarsk intelligentsia in accordance with the position of the Bolsheviks, resulting in wishing the defeat of "their government".

The newspaper "Krasnoyarskii Rabochii" was also used to discredit the well-known generals of the First World War in order to create defeatism, so that the Bolshevik would gain from this. The newspaper reprinted the articles from "III International". General A.A. Brusilov, who had virtually ensured a radical turn in the war course, was depicted as reactionary because "he opposed the convening of the Constituent Assembly and spoke about foreign ethnic influence in Petrograd, alien to the true Russia. Газета ней «выступал против созыва Учредительного собрания и говорил об инородческом влиянии в Петрограде, чуждом истинной России».

Adults read mainly newspapers and less often magazines, they did not request books. In a year the number of subscribers to newspapers doubled, but three-quarters of them were children. Adults had no time to read books due to the need to survive in a crisis, and the literacy rate was still low.

Some researchers rightly stated in the study (Drobysheva, 2013, p. 67) that the representatives of this generation had diverse and in general common axiological space. The war generation may include not only the veterans and the rear area workers, but also those who fled from the

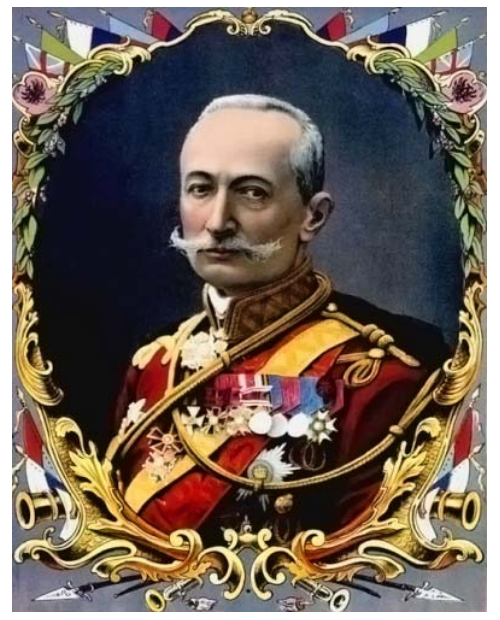

battle field and criminal elements. In Krasnoyarsk the government was struggling with the "flying squads" of marauders who traveled in the cars of the first and second class with fake documents, demanded the steam locomotive when the team of workers changed and laughed while saying "Gavrila, steer the wheel!" Each trip brought them a profit of several thousand rubles.

During the First World War Yeniseysk Governorate received military orders, and the economy began to be switched to warfooting. The functions of the Krasnoyarsk branch of the Siberian railway expanded. The state and public help was given to veterans and their families. The authorities were more demanding and punished people for violations of military discipline, drunkenness and speculation of military uniform. The prices rose and the standard of living decreased. There were certain problems of refugees and the war prisoners, but the political and musical life intensified in Krasnoyarsk.

\section{References}

Chernosvitov, P. (2013). Kollektivnaia pamiat' kak pole izvlecheniia sotsial'nykh smyslov [Colective memory as a field of extraction of social meaning], In Voprosy kulturologii [The issues of culturology], 10, 92.

Drobysheva, E. (2013). Pokolenie kak factor kul'turnoi arkhitektoniki [Generation as a factor of cultural architectonics], In Voprosy kul'turologii [The issues of culturology], 10, 67. 
Krasnoyarskii Rabochii [Krasnoyarsk worker] (1918). June, 2.

Lager' dlia voennoplennykh, on zhe pervyi krasnoiarskii kontslager' [555. A camp for the prisoners of war, the $1^{\text {st }}$ Krasnoyarsk concentration camp], available at: http://kraevushka.livejournal. com/157355.html (accessed 7 September 2015)

Romanova, E. A. (2014). Region Rossii v period Pervoi mirovoi voiny: Eniseiskaia guberniia i Krasnoyarsk [A region of Russia in the First World War period: Yeniseysk Governorate and Krasnoyarsk], In Materialy III Mezhdunarodnoi nauchno-prakticheskoi konferentsii "Nauka $v$ sovremennom informatsionnom obshchestve" [Proceedings of the Third International scientific conference "Science in modern information society"], 2, 26. North Charleston, USA.

Sviatoslavskii, A. (2013). Istoriia Rossii v zerkale pamiati. Mekhanizmy formirovaniia istoricheskikh obrazov [The history of Russia in the memory mirror. Mechanisms of forming of historical images]. Moscow, Drevnekhranilishche, 2013, 592 p.

\title{
Тыл Енисейской губернии \\ в период Первой мировой войны
}

\author{
Е.А. Романова \\ Красноярский государственный институт искусств \\ Россия, 660049, Красноярск, ул. Ленина, 22
}

\begin{abstract}
В связи с усилением внимания к проблемам изучения культуры памяти и столетием начала Первой мировой войны в данной статье рассматривается работа военно-промышленных комитетов и железнодорожных мастерских, «сапожный» и продовольственный кризис, безработииа, благотворительная деятельность сибирских запасных полков и работа с военнопленными. Анализируется и вызванная необходимостью военного времени борьба с алкоголем. Исследовались: издание газет, театральная деятельность и работа с политическими ссыльными, влиявщие на формирование общественного сознания в Енисейской губернии. В результате складывается картина не только помощи фронту, но и выживания населения Енисейской губернии и беженщев в военные годы.
\end{abstract}

Ключевые слова: Первая мировая война, тыл Енисейской губернии. появление новых общественных организаций.

Научная специильность: 24.00.00 - культурология. 